\title{
Incorrect disposal of medications: integrative literature review
}

\begin{abstract}
Ewerton de Carvalho Nascimento ${ }^{1}$, Andrezza Fabianni Pedrosa dos Santos Lima ${ }^{2}$, Emilly Tainá Batista da Silva ${ }^{3}$, Emivaldo Batista da Silva ${ }^{4 *}$, Joana Bulhões Alvares da Silva Lima ${ }^{5}$, Valéria Correia Barbosa $^{6}$, Valquiria da Silva Gomes ${ }^{7}$, Rafaela Greta Bezerra dos Santos ${ }^{8}$, José Claudionor da Silva ${ }^{9}$, Wanderson Cleyton da Silva ${ }^{10}$, Victor Daniel Barros da Silva ${ }^{11}$, Guilherme Expedito Rosendo da Silva $^{12}$, Jacicleide Maria de Souza ${ }^{13}$, Vivian Helen de Albuquerque ${ }^{14}$, Arlan Cassio de Aguiar ${ }^{15}$, Rute Maria Siqueira Silva ${ }^{16}$, Camilla Guadallupe de Oliveira Lima ${ }^{17}$, Júlio César da Silva Bruce ${ }^{18}$, Lyzandra Leticya de Lima Costa ${ }^{19}$, Eloizy Victoria da Silva ${ }^{20}$,Emanuella Barros de Souza Oliveira Alvares $^{21}$, Rafaela Damasceno Sá ${ }^{22}$
\end{abstract}

1,4,5,9,10,14,18,19 Department of Pharmaceutical Sciences, University Center of Vitória de Santo Antão - (UNIVISA) Vitória de Santo Antão, Brazil.

2,12 Department of Nutrition, University Center of Vitória de Santo Antão - UNIVISA, Vitoria de Santo Antão

3 Department of Biomedicine, Post-Graduation in Laboratory Clinical Microbiology (ASCES- UNITA) Caruaru - PE

20 Department of Biomedicine, University Center of Vitória de Santo Antão (UNIVISA)

10,13,15 Department of Full Degree in Biology, University Center of Vitória de Santo Antão (UNIVISA), Vitória de Santo Antão, Brazil .

11 Department of Physical Education, UNIBRA- Recife- PE

6.7,16,17 Nursing Department, Centro Universitario da Vitória de Santo Antão - (UNIVISA), Vitória de Santo Antão, Brazil

21,22 Department of the Faculty Center of the University Center of Vitória de Santo Antão (UNIVISA)

E-mail adresses: ewertoncarvalho1@gmail.com1 (Ewerton de Carvalho Nascimento), andrezzafpslima@hotmail.com2 (Andrezza Fabianni Pedrosa dos Santos Lima), emilly.taina@hotmail.com3 (Emilly Tainá Batista da Silva), emivaldobatista4@gmail.com4 (Emivaldo Batista da Silva), joanafarmacia2018@gmail.com5 (Joana Bulhões Alvares da Silva Lima),valeriacorreiabarbosa2@gmail.com6 (Valéria Correia Barbosa), kilgomessilva10@gmail.com7 (Valquiria da Silva Gomes), rafaelagreta2@gmail.com8 (Rafaela Greta Bezerra dos Santos Silva), j.c.silva.farma10@gmail.com9 (José Claudionor da Silva), professorwanderson2201@gmail.com10 (Wanderson Cleyton da Silva), victordanie1.0@hotmail.com11 (Victor Daniel Barros da Silva), guilhermenutri1@gmail.com12 (Guilherme Expedito Rosendo da Silva), jacicleidesouza.07@hotmail.com13 (Jacicleide Maria de Souza), vivianalbuquerque902@gmail.com14 (Vivian Helen de Albuquerque), arlan.aguiar@hotmail.com15 (Arlan Cassio de Aguiar), rutesiqueira06@gmail.com16 (Rute Maria Siqueira Silva), camillaguadallupe@gmail.com17 (Camilla Guadallupe de Oliveira Lima), julio.2017186009@univisa.edu.br18 (Júlio César da Silva Bruce), lyzandra.2017286033@univisa.edu.br19 (Lyzandra Leticya de Lima Costa), eloizyv@gmail.com20 (Eloizy Victoria da Silva), emanuella.barros@hotmail.com21 (Emanuella Barros de Souza Oliveira Alvares), rafaeladamasceno288@gmail.com22 (Rafaela Damasceno Sá)

*Corresponding author

\section{To cite this article:}

Nascimento, E.C.; Lima, A.F.P.S.; Silva, E.T.B.; Silva, E.B.; Lima, J.B.A.S.; Barbosa, V.C.; Gomes, V.S.; Santos, R.G.B..; Silva, J.C.; Silva, W.C.; Silva, V.D.B.; Silva, G.E.R.; Souza. J.M.; Albuquerque, V.H.; Aguiar, A.C.; Silva, R.M.S.; Lima, C.G.O.; Bruce, J.C.S.; Costa L.L.L.; Silva, E.V.; Álvares, E.B.S.O.; Sá, R.D. Incorrect disposal of medications: integrative literature review. International Journal of Sciences. Vol. 3, No. 1, 2022, pp.94-98. ISSN 2763-5392.

Received: 11 24, 2021; Accepted: 12 26, 2021; Published: 01 15, 2022

\footnotetext{
Abstract: Drug disposal is of concern to public health, as toxic waste can be considered depending on the composition and degree of toxicity. Therefore, they cannot have the same destination as waste considered common. Humans are responsible for disposal, be it expired drugs, leftovers, disuse or excess. Certainly, the impact on the environment is worrying and unprecedented, in addition advertising aimed at the sale of medicine stimulates the consumer and with this waste is generated. In the results of the present study, it can be seen that the number of people who dispose incorrectly prevails compared to the number of housings studied, thus the objective of the present study is to emphasize knowledge in general relation to the disposal of medications. For
} 
2 Nascimento, E.C.; Lima, A.F.P.S.; Silva, E.T.B.; Silva, E.B.; Lima, J.B.A.S.; Barbosa, V.C.; Gomes, V.S.; Santos, R.G.B.,; Silva, J.C.; Silva, W.C.; Silva, V.D.B.; Silva, G.E.R.; Souza. J.M.; Albuquerque, V.H.; Aguiar, A.C.; Silva, R.M.S.; Lima, C.G.O.; Bruce, J.C.S.; Costa L.L.L.; Silva, E.V.; Álvares, E.B.S.O.; Sá, R.D. Incorrect disposal of medications: integrative literature review...

the problem of bad disposal to be solved it is necessary that the information reaches people and collection points are installed.

Keywords: Drug disposal; Environment; Pharmacist.

\section{Introduction}

The development of new drug discoveries of various pharmaceutical forms has facilitated major developments in health care, and drugs are a widespread advance of widespread use. However, we have an increase in the growth of pharmacies along with a model of health care in which the objective is to treat pathologies, so the use of medicines has increased significantly and abusively, exposing people to numerous risks because of irrational use (ALENCAR et al. , 2014).

The incorrect disposal carried out by people is a subject that has been increasingly mentioned, because a large part of the population does not have the wisdom of the consequences reflected to the environment or the chaos carried out on public health. Around the country appear some isolated and private ideas showing how to correct the problem of disposal, offering people structures to perform it correctly (MEDEIROS et al., 2014).

These days, medicines are often used in homes, so it has been taken the habit of storing varieties of medicines at home and thus forming home pharmacies, however, there are questions such as: Where will these medicines that are stored when discarded and what impact with nature? Medications are important in the treatment of various pathologies, being essential in health care. However, WHO estimates indicate that $50 \%$ of the medications that are prescribed and dispensed are used incorrectly. Still in this same direction, according to the Centers for Disease Control and Prevention (CDC), 80 million antibiotics are inadequately prescribed (CONSTANTINO et al., 2020; ARAÚJO et al. , 2020).

Currently there is concern about the appearance of multidrug-resistant bacteria such as Escherichia coli and Klebsiella pneumoniae in the population, as the proliferation of these bacteria is increasingly rapid, intense and can cause serious infections by the incorrect use of antibiotics. Thus, serious pictures are expected by the world in the future (SILVA et al. , 2012).

Studies show more than 90 types of drugs present in the aquatic environment and present in it inactive and active metabolites, found mainly in surface waters, in Brazil, united states, European Union and Canada. The residues found in water resources present threats that are capable of causing changes in the endocrine system of humans and animals and that affect the reproduction process of the species, and is therefore a great highlight in studies of micro pollutants (RODRIGUES et al. , 2020).

For the environment the understanding of waste does not exist because in the natural cycles in which the decomposer's duty is to change materials thrown without changing the balance of nature, so for the same the understanding of residue is of anthropic origin, in which the residues of medicines do not decompose and are not absorbed (HOPPE, 2011).
In England took place one of the first researches related to environmental contamination by estrogens naturally excreted by people and toxicological echo effects at specific points where sewers are dumped and as a result estrogens were present in the waters at levels that could cause changes in the physiology of aquatic fauna. Male fish are producing the vitellogenin protein, where only female fish should produce the same through natural hormonal estrogen for egg maturation (LOPES et al. , 2010).

Endocrine disruptors are considered chemical substances that can cause interference in the correct function of the hormonal system, causing changes in intact organisms and ecosystems, which when they are in the presence of nature even at concentrations considered low can cause impairment in the growth of humans and animals (ALAMINO, 2017).

Currently, the disposal of drug residues is drafted by ANVISA resolutions 306/2004 and resolution no. 358/2005 (CONAMA), which talk about health waste management and management. Decree 5,775 of 2006 that makes the fractionation of medicines (Blisters) available for trade purposes is important for the real possible reduction of waste (SILVA et al. , 2019). On 06/05/2020, federal decree no. $10,388 / 2020$ was published, which for every 10,000 inhabitants should have at least one point for the collection of drug disposal, in order to mitigate the impact that is being caused on the environment (BRASIL, 2020).

According to the FEDERAL COUNCIL OF PHARMACY (2002 cited by COSTA et al., 2019), it is the pharmacist's duty to dispose of medicines because Art. 1 of Resolution No. 386 of the CFF, of November 2002, reports on the attributions of the same in the exercise of his profession, being: "to provide guidance on the use, custody and disposal of medicines, in order to promote rational use...". Where the goal is to see the degree of knowledge and instruction of people.

\section{Methodology}

This research consists of an integrative bibliographic review. A reading review was made from the electronic databases via Google Scholar, LILACS, PubMed, SciELO and ScienceDirect. The following keyword was used: "Conscious disposal program". Using as inclusion criteria: Scientific publications in Portuguese and articles from 2010 and as exclusion criteria: articles with restricted access, research in other languages, which are overtime, those that by title or abstract demonstrate not to be useful for this research and also those that have limitations in the chosen theme.

\section{Results and Discussion}

Table 1 shows the number of articles that were found and selected in the databases after putting into practice the 
inclusion and exclusion criteria, and in Table 2 is shown the amount found referring to the categories mentioned and in Table 3 the data of the articles used for the discussion:

\begin{tabular}{l|c|c|c}
\multicolumn{4}{l}{ Table 1. Articles found and selected on "Conscious Disposal Program" } \\
\hline No. & DATABASE & FOUND & SELECTED \\
\hline $\mathbf{1}$ & Google Scholar & 99 & 6 \\
\hline $\mathbf{2}$ & LILACS & 0 & 0 \\
\hline $\mathbf{3}$ & Pubmed & 0 & 0 \\
\hline $\mathbf{4}$ & SciELO & 0 & 0 \\
\hline $\mathbf{5}$ & ScienceDirect & 0 & 0 \\
\hline
\end{tabular}

Source: Prepared by the authors, 2021

Table 2. Categories of articles found with "Conscious Disposal Program"

\begin{tabular}{l|l|l}
\hline No. & CATEGORIES & QUANTITIES \\
\hline $\mathbf{1}$ & Environmental & 4 \\
\hline $\mathbf{2}$ & Educational & 32 \\
\hline $\mathbf{3}$ & Case Study & 36 \\
\hline $\mathbf{5}$ & Outside the Theme & 6 \\
\hline $\mathbf{6}$ & Out of Time & 12 \\
\hline $\mathbf{7}$ & Legislative & 5 \\
\hline
\end{tabular}

Source: Prepared by the authors, 2021.

Table 3. Statement of the selected studies that make up the discussion

\begin{tabular}{|c|c|c|c|c|c|c|}
\hline No. & Date & Securities & Authors & Journals & Goals & Findings \\
\hline 1 & 2020 & $\begin{array}{l}\text { Survey of } \\
\text { drugs } \\
\text { discarded } \\
\text { by the } \\
\text { population } \\
\text { of Jaraguá } \\
\text { do Sul and } \\
\text { Corupá-SC } \\
\text { through the } \\
\text { conscious } \\
\text { disposal } \\
\text { program. }\end{array}$ & $\begin{array}{l}\text { WALKE } \\
\mathrm{R}, \\
\text { Eduarda } \\
\text { Pamela } \\
\text { Schneid } \\
\text { er } \text { et al. }\end{array}$ & $\begin{array}{l}\text { Infarma- } \\
\text { Pharmace } \\
\text { utical } \\
\text { Sciences. }\end{array}$ & $\begin{array}{l}\text { Evaluate } \\
\text { discarded } \\
\text { waste } \\
\text { from the } \\
\text { cities of } \\
\text { Jaraguá } \\
\text { do Sul } \\
\text { and } \\
\text { Corupá - } \\
\text { SC. }\end{array}$ & $\begin{array}{l}\text { The } \\
\text { analysis } \\
\text { can help in } \\
\text { the } \\
\text { reduction } \\
\text { of waste. }\end{array}$ \\
\hline 2 & 2019 & $\begin{array}{l}\text { Diagnosis } \\
\text { of the } \\
\text { disposal of } \\
\text { expired } \\
\text { drugs and } \\
\text { the } \\
\text { relationshi } \\
\text { p with } \\
\text { reverse } \\
\text { logistics in } \\
\text { the city of } \\
\text { Mariana } \\
\text { (MG). }\end{array}$ & $\begin{array}{l}\text { Souza, } \\
\text { Cardoso } \\
\text { Kamylla } \\
\text {. }\end{array}$ & $\begin{array}{l}\text { Monogra } \\
\text { ph } \\
\text { Institute } \\
\text { of Exact } \\
\text { and } \\
\text { Applied } \\
\text { Sciences, } \\
\text { Federal } \\
\text { Universit } \\
\text { y of Ouro } \\
\text { Preto, } \\
\text { João } \\
\text { Monlevad } \\
\text { e. }\end{array}$ & $\begin{array}{l}\text { Have a } \\
\text { notion of } \\
\text { the } \\
\text { disposal } \\
\text { of the city } \\
\text { of } \\
\text { Mariana - } \\
\text { MG. }\end{array}$ & $\begin{array}{l}\text { Failure in } \\
\text { the } \\
\text { logistics } \\
\text { process of } \\
\text { the city, } \\
\text { because it } \\
\text { does not } \\
\text { have due } \\
\text { control. }\end{array}$ \\
\hline
\end{tabular}

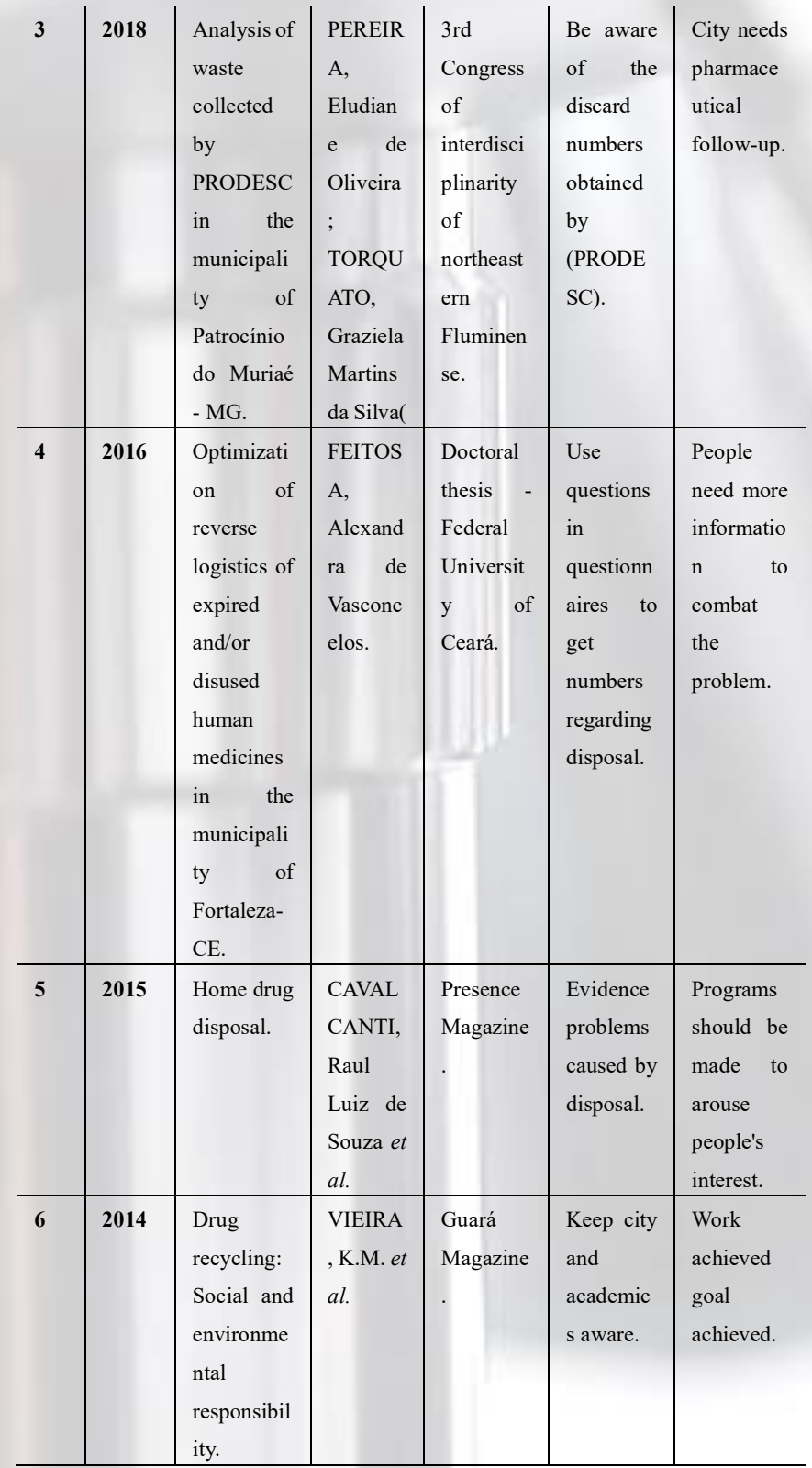

Source: Prepared by the authors, 2021.

In the municipality of Mariana - Minas Gerais, a qualitative study was carried out, where suggestions for improvements were proposed in the face of the situation found and awareness campaigns. Through the studies, we obtained the results where $74.72 \%$ of the people confirmed that they disposed of the common waste, $71.73 \%$ confirmed that they did not know about the correct way to perform the disposal and $55 \%$ said they have the knowledge of the damage that can be caused by the disposal in the wrong way (SOUZA, 2019).

In the descriptive and exploratory study conducted in four regions of Rio de Janeiro $87.8 \%$ of the interviewees do not perform the correct disposal, $61 \%$ do not have the science of what can be caused and $12.2 \%$ said they would discard in the recommended way. In addition to the research conducted, the participants gained incentive folders. (CAVALCANTI et $a l ., 2015)$. In the city of Fortaleza - Ceará, a qualitative study 
4 Nascimento, E.C.; Lima, A.F.P.S.; Silva, E.T.B.; Silva, E.B.; Lima, J.B.A.S.; Barbosa, V.C.; Gomes, V.S.; Santos, R.G.B..; Silva, J.C.; Silva, W.C.; Silva, V.D.B.; Silva, G.E.R.; Souza. J.M.; Albuquerque, V.H.; Aguiar, A.C.; Silva, R.M.S.; Lima, C.G.O.; Bruce, J.C.S.; Costa L.L.L.; Silva, E.V.; Álvares, E.B.S.O.; Sá, R.D. Incorrect disposal of medications: integrative literature review...

was conducted through questionnaires where the result gained was that $84.7 \%$ use the common waste for disposal, $0.5 \%$ return drugstore and $48.6 \%$ said they had a sense of the damage caused to the environment (FEITOSA 2016).

We can observe that the number of people who make the wrong disposal prevails. In relation to the knowledge of the damage caused to nature only in souza's study (2019) the amount of people who are said to be aware is greater, this shows the need for new collection points, pharmacies and health posts that collect and also that information reaches people.

According to Walter da Silva, the vice-president of the CFF, in eight stations that take care of sewage treatment, the presence of 18 chemical components related to drugs was identified and in several water collections in Germany were identified with the discovery of 36 different drugs. Among them, medications for the treatment of cholesterol, blood pressure, analgesics and anti-inflammatory drugs are present (JOÃO cited by VIEIRA et al., 2014). The wrong disposal brings problems to health, as they are micro-organic contaminants (VEIRA et al., 2014).

In the work of Walker et al. (2020) there was a study in the state of Santa Catarina in the population of Corupá and Jaraguá do Sul, boxes were distributed for drug collection in the elderly centers and basic health units (UBS) where results were obtained that of 7,528 discarded drugs $25.75 \%$ were for tuberculosis, $10.66 \%$ for blood pressure, $8.42 \%$ contraceptive medications, 5.36\% analgesics and 3.22\% for inflammation. In addition to these results obtained in the study, the percentage by prescription level was presented, being $65 \%$ tainted without retention, $20 \%$ with retention and $15 \%$ without stripe. It was concluded that drugs that do not need retention or that have a government program are the most discarded.

The study conducted in Muriaé - MG quantifies and qualified the residues of discards where the numbers obtained were represented by $62.34 \%$ of unexpired drugs and $37.64 \%$ of expired drugs out of a total of 348 discarded in the period of 11 months. Regarding the classification of the drugs found, the ones with the highest rates were hypertensive, special control, metabolic and nutritional. According to the analysis made, it was seen that the drugs that are part of the lists of municipal list of essential medicines (REMUME) and national list of essential medicines (RENAME) prevail, in addition to medications that are part of government programs (PEREIRA et al., 2018).

\section{Conclusions}

Medicines have become essential in people's reality to solve health-related problems and with this comes concern related to the way of disposal. Advertising aimed at the sale of medicine ends up encouraging consumers to buy in unnecessary quantities, with this the drugs end up winning and waste is generated. The guidance of the pharmacist is indispensable at the time of purchase in relation to the necessary amount, in addition to educational programs and incentive in social networks of greater use. Another way to bring information to people who do not yet have knowledge of the correct form of disposal would be collection point facilities in public and private pharmacies, in basic health units and health actions by the city, making the population aware of the damage to public health and the environment.

\section{Acknowledgments}

I thank God for keeping me strong throughout my graduation and given me wisdom to deal with all ups and downs. I also thank my mother Maria Carvalho, father Edvaldo Nascimento, advisor Rafaela Damasceno, teacher Emanuella Barros and friend Talita Íria for all support and understanding.

\section{References}

[1] ALAMINO, D.A.; SILVA, D.C.V.R. RISCOS ambientais e para saúde humana da liberação de compostos estrogênicos residuais em ambientes aquáticos. RECURSO ÁGUA, p. 60. 2017.

[2] ALENCAR, T.O.S. et al. Descarte de medicamentos: uma análise da prática no Programa Saúde da Família. Ciência \& Saúde Coletiva, v. 19, p. 2157-2166, 2014.

[3] ARAÚJO, A.S. et al. DESCARTE DE MEDICAMENTOS ARMAZENADOS EM DOMICÍLIOS DO BRASIL: UMA REVISÃO BIBLIOGRÁFICA. Encontro de Extensão, Docência e Iniciação Científica (EEDIC), v. 7, 2020.

[4] BRASIL. Decreto ${ }^{\circ} 10.388$, de 05 de junho de 2020. Disponível em: https://www.in.gov.br/en/web/dou//decreto-n-10.388-de-5-de-junho-de-2020260391756. Acesso em: dezembro de 2021

[5] CAVALCANTI, R.L.S. et al. Descarte domiciliar de medicamentos. Revista Presença, v. 1, n. 2, p. 56-77, 2015.

[6] CONSTANTINO, V.M. et al. Estoque e descarte de medicamentos no domicílio: uma revisão sistemática. Ciência \& Saúde Coletiva, v. 25, p. 585-594, 2020.

[7] COSTA, M.F.D. da et al. ORIENTAÇÃO SOBRE DESCARTE DE MEDCICAMENTOS EM UMA UNIDADE BÁSCIA DE SAÚDE. Journal of Biology \& Pharmacy and Agricultural Management, v. 15, n. 4, 2019.

[8] FEITOSA, A.V. Otimização da logística reversa de medicamentos de uso humano vencidos e/ou em desuso no município de Fortaleza-CE. 2016. $242 \mathrm{f}$. Tese (Doutorado em Engenharia Civil: Saneamento Ambiental) - Centro de Tecnologia, Universidade Federal do Ceará, Fortaleza, 2016. 
[9] HOPPE, T.R.G. Contaminação do meio ambiente pelo descarte inadequado de medicamentos vencidos ou não utilizados. 2011.

[10] JOÃO, W.S.J. Descarte de medicamentos. Revista Pharmacia Brasileira - Conselho Federal de Farmácia. Brasília, no 82 - junho/julho/agosto 2011. Disponível em:

http://www.cff.org.br/sistemas/geral/revista/pdf/132/ 014a016_artigo_dr_walter.pdf. Acesso em: dezembro de 2021.

[11]LOPES, L.G. et al. Estrogênios em águas naturais e tratadas da região de Jaboticabal-São Paulo. Química Nova, v. 33, p. 639-643, 2010.

[12] MEDEIROS, M.G.; MOREIRA, L.M.F.; LOPES, C.C.G.O. Descarte de medicamentos: programas de recolhimento e novos desafios. Revista de Ciências Farmacêuticas Básica e Aplicada, v. 35, n. 4, 2014.

[13] PEREIRA, E.O.; TORQUATO, G.M.S. ANÁLISE DOS RESÍDUOS RECOLHIDOS PELO PRODESC NO MUNICÍPIO DE PATROCÍNIO DO MURIAÉMG. 2018.

[14] RODRIGUES, I.C.G. et al. Contaminação ambiental decorrente do descarte de medicamentos: participação da sociedade nesse processo. Brazilian Journal of Development, V. 6 n. 11, p. 86701-8714, 2020.

[15] SILVA, A.R.A.; WERNECK, L.; HENRIQUES, C.T. Dinâmica da circulação de bactérias multirresistentes em unidades de terapia intensiva pediátrica do Rio de Janeiro. Revista de Epidemiologia e Controle de Infecção, v. 2, n. 2, p. 41-45, 2012.

[16] SILVA, M.A.L.; SAMPAIO, J.A.R.; BANDEIRA, I.C.J. DESCARTE DE MEDICAMENTOS NO BRASIL: DESAFIOS E PERSPECTIVAS. Mostra Científica da Farmácia, v. 6, n. 1, 2019.

[17] SOUZA, K.C. Diagnóstico do descarte de medicamentos vencidos e a relação com a logística reversa no município de Mariana (MG). 2019. 90 f. Monografia (Graduação em Engenharia de Produção) - Instituto de Ciências Exatas e Aplicadas, Universidade Federal de Ouro Preto, João Monlevade, 2019.

[18] VIERA, K.M. et al. Reciclagem de medicamentos: responsabilidade socioambiental. Revista Guará, n. 2, 2014.

[19] WALKER, E.P.S. et al. Levantamento de medicamentos descartados pela população de Jaraguá do Sul e Corupá-SC por meio do programa Descarte Consciente. Infarma-Ciências Farmacêuticas, v. 32, n. 3, p. 262-270, 2020. 